Review

\title{
The HTLV-1 Virological Synapse
}

\section{Mohamed Nejmeddine * and Charles R.M. Bangham *}

Department of Immunology, Wright-Fleming Institute, Imperial College London, St. Mary's campus, Norfolk Place W2 1PG, London, UK

* Authors to whom correspondence should be addressed;

E-Mails: m.nejmeddine@imperial.ac.uk (M.N.); c.bangham@imperial.ac.uk (C.R.M.B.);

Tel.: +44-20-7594-2119 (M.N.); Tel.: +44-20-7594-3730 (C.R.M.B.);

Fax: +44-20-7402-0653 (M.N.); Fax: +44-20-7402-0653 (C.R.M.B.).

Received: 9 April 2010; in revised form: 4 June 2010 / Accepted: 29 June 2010 /

Published: 7 July 2010

\begin{abstract}
Human T-lymphotropic virus-1 (HTLV-1) spreads efficiently between T-cells via a tight and highly organized cell-cell contact known as the virological synapse. It is now thought that many retroviruses and other viruses spread via a virological synapse, which may be defined as a virus-induced, specialized area of cell-to-cell contact that promotes the directed transmission of the virus between cells. We summarize here the mechanisms leading to the formation of the HTLV-1 virological synapse and the role played by HTLV-1 Tax protein. We propose a model of HTLV-1 transmission between T-cells based on the three-dimensional ultrastructure of the virological synapse. Finally, in the light of recent advances, we discuss the possible routes of HTLV-1 spread across the virological synapse.
\end{abstract}

Keywords: HTLV-1 virological synapse; viral proteins; cytoskeleton; polarization

\section{Introduction}

Human T-lymphotropic virus type 1 (HTLV-1) is a complex retrovirus, classified in the Deltaretrovirus genus of the subfamily Orthoretrovirinae. The majority (about 95\%) of infected individuals develop no associated disease (asymptomatic carriers; ACs). However, in a small fraction of individuals, infection results in one of two types of disease: about 2-5\% develop adult $\mathrm{T}$ cell leukemia/lymphoma (ATLL) [1], and a further $0.5-3 \%$ develop one or more of a range of 
inflammatory diseases. The most common of these conditions is HTLV-1-associated myelopathy/tropical spastic paraparesis (HAM/TSP), an inflammatory disease of the central nervous system [2,3].

Until recently, it was generally believed that HTLV-1 is latent in vivo [4-6]. However, there is significant evidence to the contrary [7,8]. The presence of high frequencies of activated HTLV-1specific cytotoxic T lymphocytes (CTLs) $[9,10]$ in the peripheral blood supports the hypothesis that the virus is not latent, i.e., there is ongoing viral transcription, and that this is greater in patients with HAM/TSP than in ACs. Direct evidence for selective proliferation of HTLV-1-infected T cells was obtained by Asquith et al. (2007) by in vivo labeling with deuterated glucose [11].

In this review, we consider the mechanisms of cell-to-cell spread of HTLV-1. Following the discovery of the virological synapse (VS) in 2003, there have been significant advances in the understanding of the mechanism of formation of the synapse and in the locus of transfer of virions from cell to cell. We conclude that HTLV-1, as appears to be the case for HIV-1 and MLV, can be transferred from cell to cell both at sites of budding at the closely apposed plasma membranes at the VS and by lateral movement of preformed virions at, or near, the periphery of the cell-to-cell contact, where they may be protected in a 'biofilm' of extracellular matrix.

\section{HTLV-1 cell tropism, cell-to-cell spread and the VS}

HTLV-1 can infect a wide range of human cell types in vitro [12], but in vivo the virus is almost confined to the $\mathrm{CD}^{+} \mathrm{T}$ lymphocyte subset [13-16]. Furthermore, most of the malignancies induced by HTLV-1 are tumors of CD4 ${ }^{+} \mathrm{T}$ lymphocytes [17]. $\mathrm{CD}^{+} \mathrm{T}$ lymphocytes can also carry the virus, but at a consistently lower frequency than $\mathrm{CD} 4^{+} \mathrm{T}$ cells $[18,19]$.

The conjunction of two observations led to the postulation of the VS. First, direct cell-to-cell contact is necessary for efficient transmission of HTLV-1 from an infected cell to a new host cell, both in vitro [20,21] and in vivo [22], where transmission depends on transfer of infected lymphocytes in breast milk [23-25], semen [26] or transfused blood products [27,28]. HTLV-1 virions are typically undetectable in the serum of infected individuals by RT-PCR. Virions are produced only by certain continuous in vitro T cell lines: fresh, naturally infected lymphocytes do not produce cell-free HTLV-1 particles. Furthermore, of the cell-free HTLV-1 virions that are produced by transfected $\mathrm{T}$ cells or continuous producer $\mathrm{T}$ cell lines, only one in $10^{5}$ to $10^{6}$ is infectious [29]. Second, HTLV-1-specific T cells are themselves infected more frequently with HTLV-1 than are T cells specific to other antigens. This preferential infection was evident in both $\mathrm{CD}^{+} \mathrm{T}$ cells [18] and $\mathrm{CD} 4^{+} \mathrm{T}$ cells [30]. These two observations raised the possibility that HTLV-1 transmission was assisted by the process of $\mathrm{T}$ cell antigen recognition. More precisely, HTLV-1 might spread across the 'immunological synapse' [31], the specialized area of contact that is formed between a lymphocyte and another cell in which distinct protein microdomains mediate adhesion, antigen recognition and secretion of cytokines or lytic granules. Confocal microscopy of conjugates formed spontaneously between ex vivo $\mathrm{CD}^{+}$cells from an HTLV-1-infected person and autologous (or allogeneic) lymphocytes revealed a structure at the cell-cell junction, which indeed resembled the immunological synapse [32]. Polarization of the adhesion molecule talin and the microtubule organizing center (MTOC) to the cell-cell junction was accompanied by accumulation of the HTLV-1 core protein Gag and the HTLV-1 genome at the 
cell-cell junction. After $2 \mathrm{~h}$, both the Gag protein and the HTLV-1 genome were transferred from the infected to the uninfected cell [32].

A critical observation revealed the distinction between the immunological synapse and the structure formed between an HTLV-1-infected cell and another cell. In an immunological synapse, the MTOC in the responding $\mathrm{T}$ cell is polarized towards the antigen-presenting cell, such as a virus-infected cell. This polarization is triggered by engagement of the T-cell antigen receptor [33,34]. In contrast, in the cell-cell conjugates formed with an HTLV-1-infected cell, the MTOC was polarized inside the virusinfected cell, not towards it. The results are shown in Table 1 [32].

Table 1. HTLV-1-infected cells polarize their MTOCs to the cell-cell junction in CD4+ Tcell conjugates. Two experiments were performed, each with fresh ex vivo CD4+ T cells from an unrelated HTLV-1-infected subject. Conjugates were allowed to form for $30 \mathrm{~min}$ (Subject 1) or $60 \mathrm{~min}$ (Subject 2), then were fixed and stained for HTLV-1 Gag p19 and tubulin alpha. Only conjugates containing two cells were counted. The figures denote the number (percentage) of cells whose MTOC was polarized to the cell-to-cell junction. Odds ratio $^{(a)}$ of MTOC polarization in Gag p19+ cells, comparing the number of polarized MTOCs with (polarized + not seen) MTOCs. This table was originally published in the material accompanying reference [32].

\begin{tabular}{|c|c|c|c|c|c|}
\hline \multirow{3}{*}{$\begin{array}{l}\text { MTOC } \\
\text { orientation }\end{array}$} & \multirow{3}{*}{$\begin{array}{l}\text { Uninfected } \\
\text { control } \\
\text { subject }\end{array}$} & \multicolumn{4}{|c|}{ HTLV-1-infected subjects } \\
\hline & & \multicolumn{2}{|c|}{ Subject 1} & \multicolumn{2}{|c|}{ Subject 2} \\
\hline & & Gag $\mathrm{p} 19^{-}$ & Gag p $19^{+}$ & Gag p19- & Gag $\mathrm{p} 19^{+}$ \\
\hline Polarized \% & $79(18.7)$ & $85(25.9)$ & $163(58.2)$ & $45(22.0)$ & $59(53.2)$ \\
\hline Not polarized $\%$ & $322(76.3)$ & $217(66.2)$ & $111(39.6)$ & $160(78.0)$ & $52(46.8)$ \\
\hline Not seen & $21(5)$ & $26(7.9)$ & $6(2.1)$ & $0(0.0)$ & $0(0.0)$ \\
\hline Total & $422(100.0)$ & $328(100.0)$ & $280(99.9)$ & $205(100.0)$ & $111(100.0)$ \\
\hline \multirow{2}{*}{$\begin{array}{l}\text { Odd ratio }^{\text {a }} \\
\text { (95\% confidence } \\
\text { interval) } \\
\chi^{2}=(\mathrm{P}<<0.001)\end{array}$} & \multirow[b]{2}{*}{-} & \multicolumn{2}{|c|}{$\begin{array}{c}3.98(2.83-5.61) \\
\chi^{2}=63.9(\mathrm{P}<<0.001)\end{array}$} & \multicolumn{2}{|c|}{$\begin{array}{c}4.02(2.45-6.64) \\
\chi^{2}=30.4(\mathrm{P}<<0.001)\end{array}$} \\
\hline & & \multicolumn{4}{|c|}{$\begin{array}{l}\text { Subject } 1 \text { and subject } 2 \text { combined: } \\
\mathbf{4 . 0 7}(3.07-5.39)\end{array}$} \\
\hline
\end{tabular}

This observation showed that the mechanisms triggering the cytoskeletal polarization differed from the immunological synapse, and immediately suggested that the polarization was induced by HTLV-1 itself, perhaps in order to transmit viral material to the uninfected cell.

Inhibition of polarization and cell-to-cell transfer of HTLV-1 Gag protein at the cell-cell junction by the microtubule inhibitor nocodazole $(30 \mu \mathrm{M})$ confirmed that the donor cell's microtubule cytoskeleton plays a central part in cell-to-cell transmission of HTLV-1 [35,36]. Recently, Mazurov et al. [37] used an elegant new system of luciferase-expressing, replication-dependent vectors to quantify the infectivity of HTLV-1 and HIV-1 and the contribution of Tax protein to cell-to-cell transmission. 
These authors found that cell-to-cell transmission of HTLV-1 was $>10^{4}$ times more efficient than cellfree virus, whereas cell-to-cell transmission of HIV-1 was only two-fold more efficient. Disruption of the microtubules with nocodazole reduced HTLV-1 co-culture infectivity by $85 \%$, whereas HIV-1 infectivity was reduced by $60 \%$. In addition, the authors showed that the induction of an immunological synapse between a Raji cell and a $\mathrm{CD}^{+}{ }^{+}$target cell did not increase infection with either HIV-1 or HTLV-1 virus-like particles, suggesting that cell-to-cell infection requires the formation of a specialized VS [37]. These results confirm the exceptionally strong dependence of HTLV-1 transmission on cell-cell contact and the importance of cytoskeletal remodeling in the cell-tocell transmission of both HTLV-1 and HIV-1.

Molecular triggers and intracellular pathways that cause the cytoskeleton polarization in HTLV-1-infected cells have now been identified (see below). Because both the mechanisms and the function of the HTLV-1-induced structure were distinct from the immunological synapse, the term 'virological synapse' was used [32].

\section{Definition of the VS}

A VS may be defined as a virus-induced, specialized area of cell-cell contact that promotes the directed transmission of the virus between cells. Many viruses are known to spread efficiently by cellcell contact, but such spread typically takes place across normal, pre-existing cellular contacts. In contrast, a VS is actively induced by contact between an infected cell and another cell. The viruses that benefit most strongly from transmission by a VS are therefore those that infect mobile cells, such as leukocytes. The VS maximizes the efficiency of transmission and limits the exposure of the virus to host defense mechanisms, both in time and space.

\section{Polarization of viral proteins at the VS}

The distribution of the HTLV-1 proteins Gag, Env and Tax can be visualized by confocal microcopy (Figure 1), and electron microscopy (Figure 2) in naturally infected cells [32,35,36,38-41]. In a single isolated cell (not making contact with a target cell) Gag is detected in the cytoplasm, forming large cytoplasmic inclusions whose precise nature remains unknown [42]. These inclusions appear to be randomly distributed around the periphery of the cell under the plasma membrane. Virions may also accumulate on the outside of the plasma membrane of an isolated cell, in the extracellular matrix ([93]: see Section 9 below). Env protein is uniformly distributed around the plasma membrane in an isolated cell; Tax protein is mostly nuclear but a significant fraction of Tax is present around the MTOC in association with the cis-Golgi compartment [35,43-45]. The distribution of Tax protein between the nucleus and the cytoplasm depends on the balance between ubiquitylation and sumoylation $[44,46]$. In cell conjugates formed between an HTLV-1 infected T-lymphocyte and autologous cells, the Gag and Env proteins are characteristically polarized toward the region of contact formed with the target cell $[32,35,36,41]$. In about $30 \%$ of cell-cell conjugates, a fraction of Tax also appears at the inner side of the plasma membrane in the region of cell-to-cell contact [35]: the function of Tax protein in this location is unknown. The mechanisms by which the HTLV-1 proteins are transported, sorted and delivered to the VS also remain unclear. 


\section{Polarization of the cytoskeleton to the VS}

The formation of the VS is accompanied by the polarization of the MTOC in the infected cell toward the cell contact formed with the target cell (Figure 1). This polarization is a good indication of the establishment of a VS [32,35,36,47]. The polarization depends on the integrity of both actin and microtubule components of the cytoskeleton and requires the activity of the small GTPases Rac1 and Cdc42 [35].

As described above, the observation that the MTOC polarizes towards the cell-cell junction inside the HTLV-1-infected cell, rather than in a T cell responding to an antigen, revealed the distinction between the VS and the immunological synapse. The trigger that causes the microtubule polarization in the VS therefore cannot be delivered by the T-cell antigen receptor. It was thus postulated that two signals were required to trigger the MTOC polarization observed at the VS: one from cell-cell contact and one from the viral infection itself. Specifically, it was hypothesized that engagement of a receptor on the surface of the infected cell acted in synergy with a signal from an intracellular HTLV-1 protein to trigger the observed polarization.

Figure 1. Polarization of HTLV-1 proteins and the microtubules network toward the VS formed between autologous CD4+ cells naturally infected with HTLV-1. (A-C) HTLV-1 Gag protein. (D) HTLV-1 Tax protein. (A) Isolated cell. (C-D) autologous CD4+ conjugates. Scale bars $=10 \mu \mathrm{m}$. Originally published in Journal of Biological Chemistry [35].

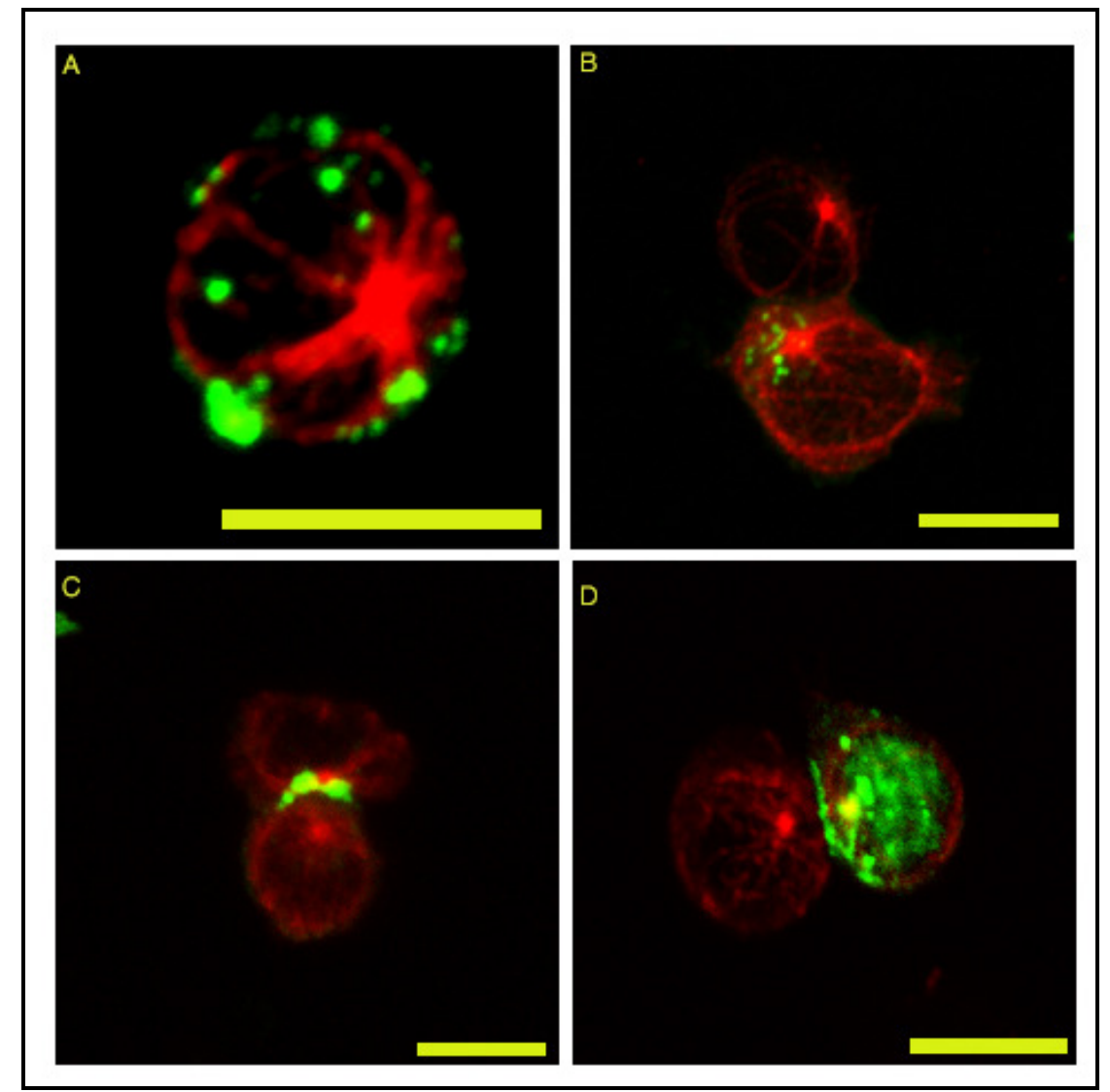




\subsection{Cell surface trigger of MTOC polarization at the VS}

To identify the signal from cell-cell contact, latex beads coated with monoclonal antibodies were used to cross-link certain molecules on the surface of the infected T cell. As expected, cross-linking of the $\mathrm{T}$ cell receptor with an anti-CD3 monoclonal antibody caused efficient polarization of the MTOC towards the coated latex bead [47]. In fact, cross-linking of a number of other cell-surface molecules also triggers MTOC polarization [47], demonstrating the unusual mobility of the T cell's microtubule cytoskeleton. However, engagement of either of two molecules, ICAM-1 (CD54) or the IL-2 receptor alpha chain (CD25), caused a significantly higher frequency of MTOC polarization in HTLV-1infected cells than in uninfected cells. The importance of ICAM-1 in triggering MTOC polarization was corroborated by two further observations. First, a soluble cyclic peptide derived from the region of LFA-1 that normally binds to ICAM-1 selectively inhibited the observed preferential MTOC polarization in HTLV-1-infected cells towards an uninfected cell. Second, the selective MTOC polarization in HTLV-1-infected cells was abolished when the target cell lacked LFA-1, but was enhanced when the target cell expressed the constitutively actively form of LFA-1 [47]. The reason for selective polarization towards CD25 is less obvious: we have suggested that this results from the known physical association between CD25 and ICAM-1 in the T cell plasma membrane [48].

\subsection{Intracellular trigger of MTOC polarization at the VS}

The signal from ICAM-1 cross-linking was especially effective in triggering cytoskeletal polarization in cells infected with HTLV-1. What was the signal from HTLV-1 infection that acted in synergy with the ICAM-1 signal? The Tax protein of HTLV-1 was a strong candidate, because of its early and abundant expression during HTLV-1 replication and its known capacity to transactivate genes via the CREB, NF- $\kappa$ B and SRF pathways [44,46,49-53]. By transfecting a Tax expression plasmid into Jurkat $\mathrm{T}$ cells, we showed [35] that Tax is indeed sufficient to explain the observed preferential cytoskeletal polarization in HTLV-1-infected cells. We then used a series of mutants of the Tax protein to investigate the relationship between the signaling pathways activated by Tax, the intracellular localization of the Tax protein, and its ability to trigger MTOC polarization.

Mazurov et al. [37] have recently quantified the contribution of Tax to the efficiency of HTLV-1 transmission across the VS. Their results showed that Tax protein increased the efficiency of HTLV-1 transmission by more than 10-fold, confirming the earlier observations [35]. Remarkably, Tax also increased the efficiency of cell-to-cell transmission of HIV-1 by more than 10-fold, and the authors concluded that HTLV-1 Tax protein is a major determinant of the difference between HTLV-1 and HIV-1 transmission.

The cross-linking of ICAM-1 (reviewed in [54]) activates two distinct signaling pathways: one is RhoA-dependent [55], and the other involves Ras-MEK-ERK activation [56]. We previously showed that MTOC polarization in HTLV-1-infected cells is independent of RhoA GTPase activation [35]. Our recent data, obtained both in naturally infected lymphocyte and transfected Jurkat T-cells, confirms that MTOC polarization induced by the cross-linking of ICAM-1 depends on the Ras-MEK-ERK pathway [36]. This pathway is distinct from that activated by TCR engagement [36]. Indeed, HTLV-1 
infection significantly reduced the frequency of MTOC polarization caused by cross-linking TCR (CD3) on the cell surface [47], which suggests a competition between the two pathways.

The identification of the major triggers involved in causing preferential microtubule polarization towards the VS provided a possible resolution of the long-standing paradox that HTLV-1 infection is almost confined to $\mathrm{T}$ cells in vivo, whereas it can infect almost any nucleated mammalian (and some avian) cells in vitro. First, the role of ICAM-1 can explain preferential transmission to LFA-1-positive cells, the great majority of which are $\mathrm{T}$ cells. Second, the role of microtubule polarization suggests that HTLV-1 has evolved specific mechanisms to subvert the unusual mobility of the $\mathrm{T}$ cell cytoskeleton in order to propagate. This in turn can explain the observation that, whereas HTLV-1 can infect other cell types in vitro such as epithelial cells and fibroblasts [29,57], it is not possible to propagate HTLV-1 in these cell types. That is, HTLV-1 can enter other cell types, but the infected cell is unable to pass the virus on to other cells.

In view of the observed sensitivity of the T cell's microtubule cytoskeleton to engagement of a range of cell-surface molecules, it is likely that several ligand-receptor interactions contribute to cellto-cell transmission of HTLV-1 [58,59]. However, the conclusion that ICAM-1 plays a particularly important role is reinforced by the observations that cross-linking of ICAM-1 can increase HTLV-1 protein expression [60], and conversely, HTLV-1 infection upregulates expression of ICAM-1 on the infected cell surface [61-64].

\section{Transfer of viral protein and genome to target cells}

Confocal microscopy was used to examine the distribution of HTLV-1 Gag and Env proteins and the HTLV-1 genome in fresh, unstimulated peripheral blood mononuclear cells (PBMCs) isolated directly from HTLV-1-infected individuals [32]. $\mathrm{CD}^{+}$or $\mathrm{CD}^{+} \mathrm{T}$ cells isolated from a HAM/TSP patient were allowed to form conjugates with $\mathrm{T}$ cells from a healthy uninfected donor for $120 \mathrm{~min}$ : in addition to accumulation of Gag p19 staining at the cell-cell junction, there was frequent Gag p19 staining in the cells derived from the uninfected donor [32,35,41]. In addition to Gag protein, HTLV-1 RNA was also transferred from infected cell to uninfected cell [32]. The HTLV-1 Gag p19 was observed to transfer from $\mathrm{CD} 4^{+} \mathrm{T}$ cells and $\mathrm{CD} 8^{+} \mathrm{T}$ cells to both $\mathrm{CD} 4^{+}$and $\mathrm{CD} 8^{+}$allogeneic $\mathrm{T}$ cells. This process may represent the initial establishment of HTLV-1 infection in a newly infected individual, which involves contact between allogeneic lymphocytes. Polarization of Gag complexes to the cell-cell junction and transfer to the uninfected cell were also observed in conjugates between CD ${ }^{+}$ $\mathrm{T}$ cells and both B cells and NK cells [32]. The kinetics of HTLV-1 Gag transfer showed a peak intensity between 90 and 210 minutes after initiation of conjugate formation [36]. This kinetics closely resembles the kinetics of the cell-to-cell transfer of HIV-1-Gag recently reported [65]. HTLV-1 transfer is significantly reduced within this time frame either by depolymerization of the cytoskeleton (microtubules or microfilaments) or by inhibition of ERK phosphorylation and CREB activation in the infected donor T-cell [36]. 


\section{Role of microtubule cytoskeleton in the cell-to-cell transfer of Gag protein}

The microtubule organizing center (MTOC) is typically oriented to the area of cell-to-cell contact in lymphocyte conjugates where it lies immediately adjacent to the accumulation of HTLV-1 Gag protein $[32,35,36]$. This close apposition of polarized Gag molecules to the MTOC suggested that the microtubule cytoskeleton affected the polarization of Gag. In conjugates formed between infected and uninfected $\mathrm{CD}^{+} \mathrm{T}$ cells, depolymerization of the microtubule network blocked the polarization and transfer of Gag protein [32,35,36]. There is a significant association between MTOC polarization and Gag positivity in conjugates between autologous $\mathrm{CD}^{+}$and $\mathrm{CD}^{+} \mathrm{T}$ cells from an infected individual [32].

Recently, the HTLV-1 accessory protein p12 was reported to reduce the expression of ICAM-1/2, which in turn prevents the destruction of HTLV-1-infected cells by NK cells [66]. In addition p12 has been shown to induce LFA-1 clustering on the surface of infected $\mathrm{T}$ cells via a calcium-dependent signaling pathway, which is thought to promote HTLV-1 spread between T cells [67]. HTLV-1 Tax expression was also shown to strongly up-regulate ICAM-1 expression [61]. Thus, HTLV-1 appears to regulate the expression of adhesion molecules at the surface of infected T-cell using both Tax and p12 protein. However, the early expression of Tax protein and its powerful effect on ICAM-1 suggests that Tax will dominate - and so upregulate ICAM-1 - in the early stages of the infectious cycle, so promoting the formation of the VS.

The association of Tax protein with the MTOC region in the infected T cell and its ability to activate CREB pathway are both required for the polarization observed during the formation of the HTLV-1 VS [36]. Tax also binds directly to the protein kinase MEKK1 [68], and this interaction might play a part in the synergistic induction of MTOC polarization by Tax and ICAM-1. However, Tax protein interacts with a large range of cellular proteins, including Ras p21 proactive 2 and cdc42/Rac effector kinase [69], which are a part of the Ras activation pathway.

\section{Ultrastructure of the VS: Electron tomography}

We investigated the three dimensional ultrastructure of the HTLV-1 VS using electron tomography (Figure 2) of immunostained conjugates formed between $\mathrm{CD}^{+} \mathrm{T}$ cells from HTLV-1-infected individuals and conjugates between MS9 cells (a chronically HTLV-1-infected cell line) and Jurkat cells [41].

Enveloped HTLV-1 particles were identified in an intercellular space or "synaptic cleft" in the VS formed between a naturally infected lymphocyte and an autologous target lymphocyte (Figure 2). Each synaptic cleft is characteristically bounded by the tightly apposed membranes of the infected and target cells, with a membrane-membrane distance of $\sim 20 \mathrm{~nm}$ (median $25.7 \mathrm{~nm}$ ). This distance is consistent with measurements of intercellular separation between lymphocytes and target cells, and with data on the conformation of ICAM-1/LFA-1 binding from electron microscopy and X-ray crystallography [70-72]. However, the ultrastructural studies of the VS show that in the case of HIV-1 the intercellular space is less tight than in the HTLV-1 VS and is therefore likely to be accessible to inhibitors both during and after virus assembly [73]. 
Figure 2. Three-dimensional ultrastructure of the VS. Enveloped HTLV-1 virions are trapped in multiple isolated synaptic clefts. Cell-to-cell transmission of HTLV-1 as observed in tomograms of the VS formed between HTLV-1 infected CD4+ T-cell (PBMC) and an autologous uninfected CD4+ T-cell as a target cell. These cells were stained against HTLV-1 Gag p19 matrix protein with a specific monoclonal antibody. (A, B) Projections along the $\mathrm{z}$-axis of two subvolumes of the same tomogram showing viral transmission at two different locations. (C) Surface representation of the VS shown in (A, B): Several virions (blue) are trapped between the closely apposed plasma membranes (yellow). (D) Tomogram slice showing an HTLV-1 particle held between the cell membranes. (E) Surface representation of the virus transmission shown in D (cell membranes: yellow and orange, virus envelope: blue, virus core: magenta). (F, G) Tomogram slices through the two areas of virus transmission shown in (A) and (B), respectively, with a spacing of about $17 \mathrm{~nm}(\mathrm{~F})$ and $25 \mathrm{~nm}(\mathrm{G})$ between subsequent slices. Black arrows indicate a protrusion linking the virus with the cell membrane. (H) Subsequent slices through the area of virus transmission shown in (D) with a spacing of about $17 \mathrm{~nm}$. Black arrows indicate a protrusion linking the virus with the cell membrane. Scale bars: A, B $300 \mathrm{~nm}, \mathrm{D} 500 \mathrm{~nm}$, F, G 100 nm, H 200 nm. This figure was originally published in PLoS One [41].

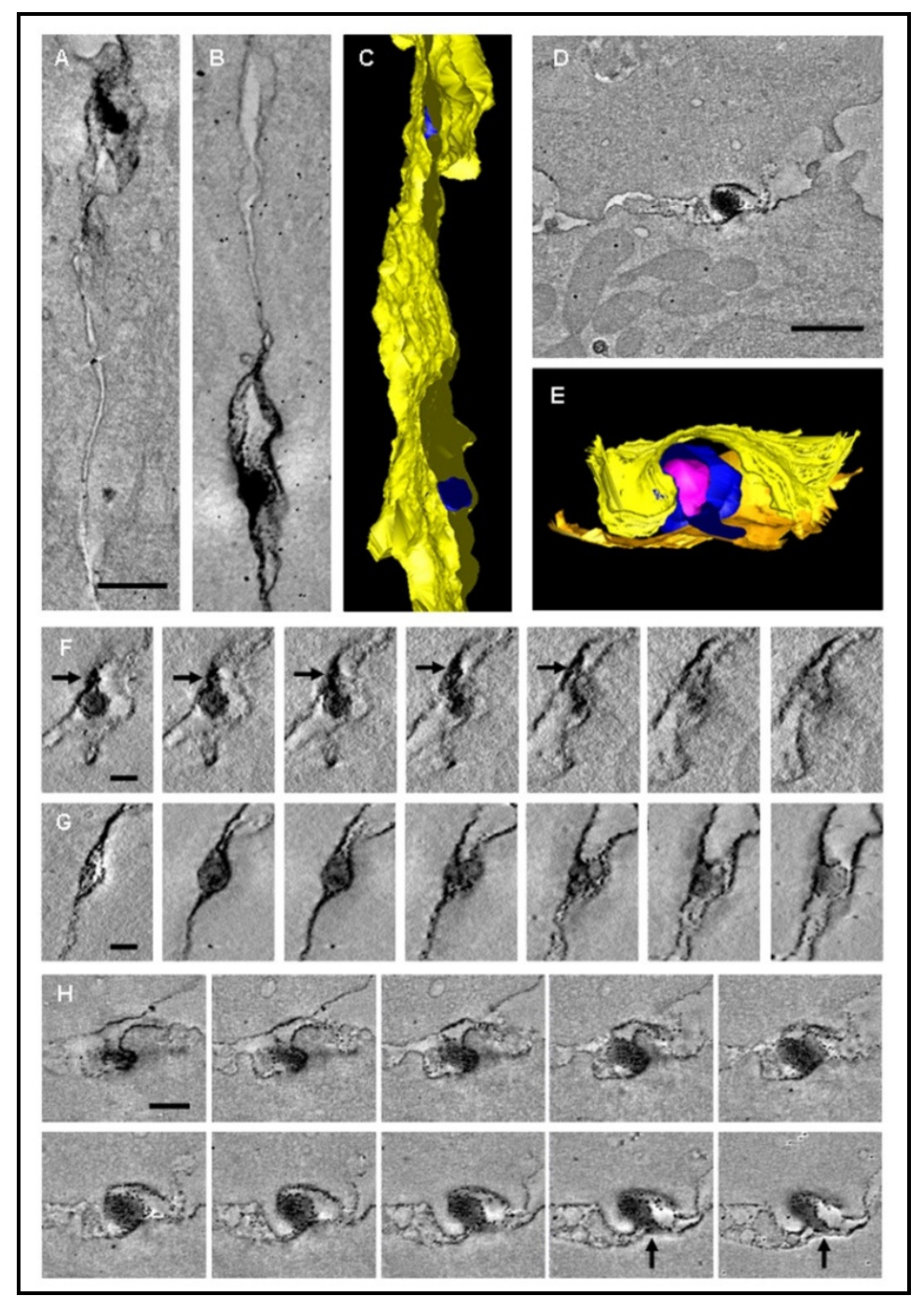


The HTLV-1 VS typically contains more than one synaptic cleft, spatially distinct and separated by areas of close membrane-membrane apposition (Figure 2, A-C). The membrane of the synaptic pockets presents sites of virus budding, and the pockets contain enveloped HTLV-1 particles [41]. This contrasts with the immunological synapse where secretory lysosomes are secreted into a single synaptic pocket in the cytotoxic synapse [74,75]. The size of HTLV-1 particles that originate from naturally infected $C D 4^{+} \mathrm{T}$ cells has a wide range $(62 \mathrm{~nm}-173 \mathrm{~nm})$, with a peak at about $100 \mathrm{~nm}$ similar to the variability in size of HIV-1 particles [76,77]. The directional nature of the process is indicated by the polarization of Gag and Tax proteins, and the MTOC [32,35,47]. The accumulation of mitochondria near the VS (Figure 2, D) again resembles the immunological synapse [41,75].

The ultrastructure of the HTLV-1 VS reconciles the requirement for cell contact and HTLV-1 Env protein for the spread of the virus, with the lack of detection of cell-free virions in the serum. Whereas most viruses spread by releasing large numbers of virions from the infected cell, HTLV-1 uses the mobility of the host cell to propagate from cell to cell. Sequestration in the synaptic cleft presumably allows efficient transfer of small numbers of virions, and may give the virions a degree of protection from components of the immune response (complement system and antibodies) (Figure 3, A1).

\section{Recent advances}

New routes have been recently described that may contribute to HTLV-1 spread in vivo. Jones and co-authors investigated the role of human dendritic cells (DCs) in the transmission of HTLV-1 [78]. DCs are potent antigen-presenting cells that play a central role in initiating the immune response. However, infection of DCs can impair their ability to mount an appropriate immune response. Indeed, many viruses infect DCs to facilitate their transmission including the retrovirus HIV-1 and the mouse mammary tumor virus [79-81]. Some viruses use the trafficking proprieties of DCs to facilitate their transport from the periphery to lymph nodes where they infect target cells.

Jones et al. have shown that myeloid DCs (mDC) and plasmacytoid DCs (pDC) are efficiently and reproducibly infected in vitro with cell-free HTLV-1 virions released by chronically infected $\mathrm{T}$ cell lines (MT2, DB1) [78]. The infected DCs can rapidly transfer HTLV-1 to autologous primary CD4 ${ }^{+}$ $\mathrm{T}$-cells, resulting in a chronic productive infection of $\mathrm{CD}^{+} \mathrm{T}$ cells ex vivo. The DC-T cell transmission of HTLV-1 is reduced by blocking Neuropilin-1 (NP-1) and heparin sulfate proteoglycans (HSPGs) [78], two molecules involved in the initial interaction of HTLV-1 with CD4 ${ }^{+}$T-cells [82-85] and in the DC-T cell interaction [86,87]. DC-specific ICAM-3-grabbing nonintegrin (DC-SIGN) was also shown to facilitate the interaction of dendritic cells with HTLV-1-infected cells [88]. Recently it was reported that blocking any one of four molecules HSPGs, NRP-1, GLUT-1 or DC-SIGN led to reduction of virus binding to the cell; however, HTLV-1 transmission from DCs to T cells was mediated primarily by DC-SIGN [89]. Based on their findings and on the studies reporting the presence of viral proteins [90] and genome [91,92] in DCs isolated from HTLV-1-infected individuals, Jones et al. suggested that cell-free virus can also infect DCs in vivo (Figure 3, A2). It is possible that DCs play an important part in the early stages of HTLV-1 infection of a new host, by efficiently acquiring the virus and disseminating it to $\mathrm{T}$ cells. This system provides a new approach for dissection of the early events in HTLV-1-induced transformation and HTLV-1 infection. 
Figure 3. Illustration of possible routes of HTLV-1 spread between cells in vivo. (A) cell-to-cell transmission via intercellular synaptic cleft surrounded by a tight cell-cell contact between the donor and recipient cell, 1. Cell-free particles can be internalized by dendritic cells and are then transferred to lymphocyte only by cell-to-cell contact, 2 . Virus particles can be retained on the cell surface in a biofilm-like-structure before lateral transfer to the recipient outside the cell-cell contact region, 3. (B) In an isolated HTLV-1infected lymphocyte, the viral proteins are not polarized.

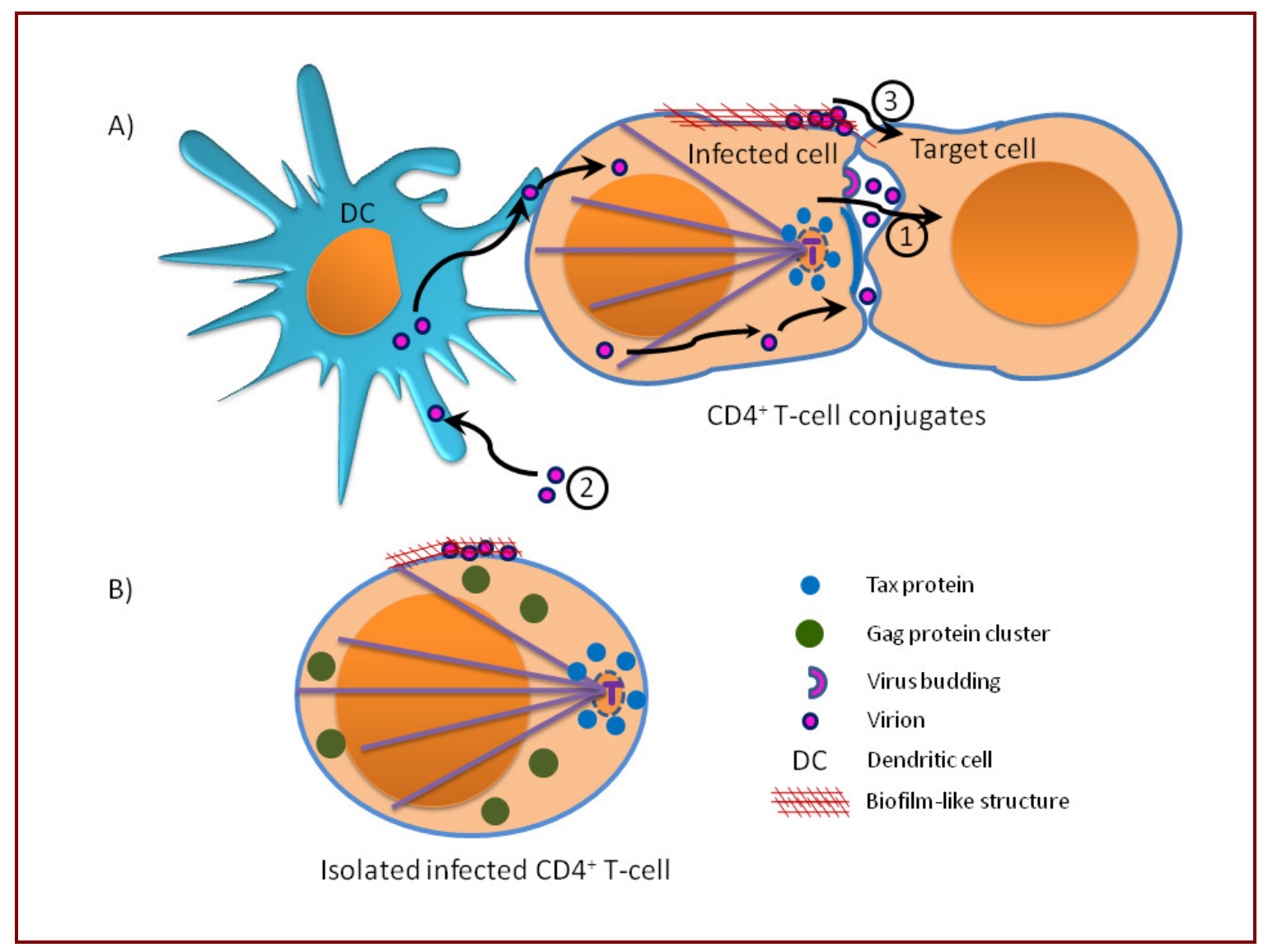

Pais-Correia et al. have reported evidence that HTLV-1 can also be transferred from cell to cell at the VS via biofilm-like extracellular viral assemblies [93]. By using electron and light microscopy analysis they detected extracellular viral clusters at the cell surface of HTLV-1 infected cell after overnight incubation in vitro. These viral assemblies are carbohydrate-rich structures, suggesting the involvement of matrix-linker proteins in the adhesion and attachment of HTLV-1 to the surface of infected cells. The authors concluded that the extracellular matrix component and cellular lectins together generate a cocoon-type structure that concentrates virions in a confined protective environment to escape the immune response. Consistent with the tomographic studies of HTLV-1-VS [41] the authors observed that infected $\mathrm{T}$ cells formed a tight contact with the target cell. However, their microscopic analysis suggested that many virions cluster overlapped the cell contact, bridging the gap between the two $\mathrm{T}$ cell surfaces [93]. Extensive washing or heparin treatment of chronically infected cells and primary infected $\mathrm{CD}^{+}$cells reduces their capacity to infect reporter target cells [93]. In contrast with an earlier report [78], the cell-free HTLV-1 particles recovered from the cell surface 
clusters by extensive washing and heparin treatment were able to infect target $\mathrm{T}$ cells, although less efficiently than by cell-to-cell contact at the VS.

Recent studies on Murine Leukemia Virus (MLV), a retrovirus related to HTLV-1, have quantified the sequential assembly and transmission events for individual viral particles in living cells [94,95]. The authors showed that MLV Gag protein is present in 10-fold greater amounts at the cell-cell contact area compared to the periphery and that the de novo assembly of virions is highly polarized toward the zone of cell-to-cell contact [94]. They also observed that a fraction of 30\% of MLV particles is retained at the infected cell surface after completion of assembly, and they named this fraction "surfacing viruses". These virions are competent for transmission to infected target cells after the establishment of a physical cell-to-cell contact [95]. This fraction may represent a reservoir of infectious virus particles that can be sequestered and later passed on to uninfected target cells upon the establishment of cell-to-cell contacts.

We conclude that HTLV-1, like other retroviruses (notably HIV-1 and MLV), can be transferred between cells at more than one locus at the VS. The relative magnitude of cell-to-cell transmission of virions that bud within the cell contact zone and preformed virions at the periphery of the cell contact zone remains to be quantified (Figure 3, A3); this ratio may depend on the time interval between the onset of viral antigen expression and the formation of a cell-cell contact.

To identify and quantify the mechanisms involved in the formation and function of the HTLV-1 VS, experimental work in vitro has focused chiefly on two-cell conjugates. However, it is likely that, in vivo, an HTLV-1-expressing T-cell will make contact with more than one cell simultaneously in the low-velocity, cell-rich environment of the lymphoid circulation. HIV-1 has indeed been shown to spread in culture from one infected cell to more than one recipient cell: the authors called the multiple contact a polysynapse [96]. These rosette-like structures, displaying Gag accumulation at each cell contact, were observed in infected lymphocytes and DCs. Microscopic analysis suggests that the cell contacts in the polysynapse can be formed simultaneously rather that one after another. Multifocal capping of assembled budding virions required for polysynapse formation is promoted by tetraspanins and plasma membrane mobility via lipid rafts. The actin and microtubules are also involved because nocodazole, cytochalasin D and latrunculin B inhibit the formation of polysynapses. The description of the virological polysynapse recalled the studies of multiple immunological synapse formation by $\mathrm{T}$ cells that interact simultaneously with cells presenting different antigenic stimuli [97]. These studies showed that the MTOC moves repeatedly between the different cell-cell contacts; eventually the secretory machinery becomes selectively polarized toward the antigen-presenting cell that provides the strongest stimulus. The intensity of molecular translocation at the different synapses reflects the strength of signals received via the T-cell receptor and accessory molecules [97].

The present studies carried out in vitro and ex vivo indicate that HTLV-1 may use more than one route to spread between $\mathrm{CD} 4^{+}$T-cells. However, it is clear that efficient propagation of HTLV-1 depends on the close contact whose formation is triggered by the virus infection in the VS. While it is difficult to completely exclude the possibility of cell-free virion transmission of HTLV-1 in vivo, cell-free HTLV-1 particles are typically undetectable in serum even by RT-PCR, and transfusion of plasma or the cell-free blood product does not transfer HTLV-1 infection. It is possible that transfer of viral particles at the periphery of the VS involves the same molecular mechanisms that cause the 
polarization of HTLV-1 protein and the cytoskeleton, as described above. However, this remains to be tested.

\section{Mechanism of HTLV-1 entry: Comparison of two possible mechanisms of HIV transmission}

The mechanism by which HTLV-1 penetrates the target cells is yet to be established. Endocytosis is an obligatory entry step for enveloped viruses whose fusion proteins are activated by acidic $\mathrm{pH}$ [98]. However, HIV can mediate fusion between adjacent target cells ("fusion from without") and HIV Env expressed on effector cells promotes fusion with target cells at neutral $\mathrm{pH}$ [99].

\subsection{Fusion from without at the cell membrane in intercellular pockets at the VS}

Certain enveloped viruses such as herpes simplex virus 1 (HSV-1), Sendai virus, and many retroviruses, including $\mathrm{HIV}$, have $\mathrm{pH}$-independent fusion proteins and can therefore penetrate into cells by fusing directly with the plasma membrane. It is generally assumed that fusion events at the plasma membrane lead to productive infection, although this is difficult to prove because virus particles are also continuously endocytosed [98].

Penetration of enveloped viruses occurs by membrane fusion catalyzed by fusion proteins in the viral envelope. The machinery involved is rather simple, at least when compared to the apparatus needed for intracellular membrane-fusion events. One reason for simplicity is that viral fusion factors are used only once. Fusion activity is triggered by cues in the form of receptor binding or low $\mathrm{pH}$. They induce, as a rule, irreversible conformational changes. Membrane fusion is an elegant and effective way to deliver viral capsids into the cytosol. No macromolecular assemblies need to pass through a hydrophobic membrane barrier. The underlying principle is the same as in intracellular membrane traffic; the viral envelope is a "transport vesicle", and the capsid is the cargo [100].

\subsection{Endocytosis}

The endocytic entry route gives many advantages to the virus: (i) the endocytic vesicles are designed to traverse the barriers imposed by the cortical cytoskeleton and the highly structured cytoplasm, so endocytosis gives the virus efficient access into the cytoplasm; (ii) the incoming viruses are exposed to compartmental environments that differ from the extracellular milieu, in particular the mildly acidic $\mathrm{pH}$ in endosomes provides an essential signal that triggers penetration and uncoating; (iii) if the penetration is lytic, endosomal membrane lysis is likely to be less damaging to the cell than lysis at the plasma membrane. However, it is possible that endocytosis leads to delivery of the virus to the lysosome, a degradative compartment and a dead-end for most viruses. This is why viruses have adapted to carefully adjust the threshold $\mathrm{pH}$ for activation to match that of early (pH 6 to 6.5) or late endosomes (pH 5 to 6) [100]. The early and late endosomes constitute distinct entry sites: this has been confirmed with dominant negative mutants of endosome-associated small guanosine triphosphatases (GTPases) [101]. A constitutively inactive mutant of Rab5 (early endosome) blocked the entry of both Semliki Forest virus ( $\mathrm{pH}$ 6.2) and influenza virus ( $\mathrm{pH}$ 5.4), whereas the corresponding Rab7 mutant (late endosomes) only blocked influenza virus entry. The progress of individual virus particles through endocytic compartments can be tracked with real-time video microscopy [65,102]. Individual 
fluorescent virus particles can be observed to bind to the cell surface, diffuse along the membrane, get trapped in coated pits or caveolae, enter by endocytosis, and move along microtubules. With the use of specific fluorescent dyes, the acidification of virus particles and the fusion of the viral envelope with cellular membranes can also be monitored.

\section{Summary and Conclusions}

1. A VS may be defined as a virus-induced, specialized area of cell-cell contact that promotes the directed transmission of the virus between cells.

2. HTLV-1 relies almost exclusively on cell-to-cell transmission to spread, both within the host and between hosts. Only dendritic cells can be efficiently infected with cell-free HTLV-1: this route may be important during initial acquisition of infection. However, DCs can infect $\mathrm{T}$ cells only by cell contact.

3) The HTLV-1 VS has a large area of close (about $26 \mathrm{~nm}$ ) apposition of the plasma membranes of the infected cell and the target cell; there is no evidence of fusion between the plasma membranes of the two cells. The viral proteins Gag, Env and Tax are polarized at the cell-cell junction.

4) The integrity and function of both actin and microtubule cytoskeletons are required for the formation of the HTLV-1 VS and for transfer of HTLV-1 between cells. The MTOC is polarized to the cell-cell junction.

5) HTLV-1 Tax protein acts in synergy with crosslinking of ICAM-1 on the infected cell surface, to cause polarization of the infected cell's microtubule cytoskeleton to the VS. This polarization requires the presence, in the vicinity of the MTOC, of a Tax molecule competent to activate the CREB pathway. The ERK pathway is also required for MTOC polarization at the VS.

6) An HTLV-1-infected cell can form more than one VS simultaneously (a "polysynapse"). The multiple contacts strongly resemble the multiple immunological synapses previously demonstrated. As in the multiple immunological synapses, it is likely that the dynamic microtubule cytoskeleton of the $\mathrm{T}$ cell moves between the respective cell contacts in a multiple VS.

7) The closely apposed cell membranes at the VS are interrupted by multiple intercellular clefts or 'pockets'. Immunoelectron tomography has shown HTLV-1 Gag staining localized under the plasma membrane in these pockets. The pockets contain Gag-staining particles within the intercellular clefts consistent with the size and morphology of virions. Virions may be transferred to the target cell either across these clefts, or at the periphery of the cell contact, or (probably) both.

8) Env protein is required for infectivity of HTLV-1. Both endocytosis and fusion from without (virion fusion with the plasma membrane) may contribute to infection of the target cell; the relative importance of the two routes remains unknown.

9) The HTLV-1 VS appears to differ from the HIV-1 VS in the closeness of the cell-to-cell contact and the enhancing role of HTLV-1 Tax protein. 


\section{Acknowledgements}

We thank Tadahiko Igakura for his central role in the discovery of the VS; Graham Taylor, Gillian Griffiths, Jane Stinchcombe and Stephen Fuller for valuable collaboration, Amanda Barnard and Endre Majorovits for experimental contributions. Finally, we thank all volunteers who provided samples for research.

\section{References and Notes}

1. Uchiyama, T.; Yodoi, J.; Sagawa, K.; Takatsuki, K.; Uchino, H. Adult T-cell leukemia: clinical and hematologic features of 16 cases. Blood 1977, 50, 481-492.

2. Gessain, A.; Barin, F.; Vernant, J.C.; Gout, O.; Maurs, L.; Calender, A.; de The, G. Antibodies to human T-lymphotropic virus type-I in patients with tropical spastic paraparesis. Lancet 1985, 2 , 407-410.

3. Osame, M.; Izumo, S.; Igata, A.; Matsumoto, M.; Matsumoto, T.; Sonoda, S.; Tara, M.; Shibata, Y. Blood transfusion and HTLV-I associated myelopathy. Lancet 1986, 2, 104-105.

4. Wattel, E.; Cavrois, M.; Gessain, A.; Wain-Hobson, S. Clonal expansion of infected cells: a way of life for HTLV-I. J. Acquir. Immune Defic. Syndr. Hum. Retrovirol. 1996, 13, S92-99.

5. Richardson, J.H.; Hollsberg, P.; Windhagen, A.; Child, L.A.; Hafler, D.A.; Lever, A.M. Variable immortalizing potential and frequent virus latency in blood-derived T-cell clones infected with human T-cell leukemia virus type I. Blood 1997, 89, 3303-3314.

6. Moritoyo, T.; Izumo, S.; Moritoyo, H.; Tanaka, Y.; Kiyomatsu, Y.; Nagai, M.; Usuku, K.; Sorimachi, M.; Osame, M. Detection of human T-lymphotropic virus type I p40tax protein in cerebrospinal fluid cells from patients with human T-lymphotropic virus type I-associated myelopathy/tropical spastic paraparesis. J. Neurovirol. 1999, 5, 241-248.

7. Asquith, B.; Hanon, E.; Taylor, G.P.; Bangham, C.R. Is human T-cell lymphotropic virus type I really silent? Philos. Trans. R. Soc. Lond. B. Biol. Sci. 2000, 355, 1013-1019.

8. Wodarz, D.; Nowak, M.A.; Bangham, C.R. The dynamics of HTLV-I and the CTL response. Immunol. Today 1999, 20, 220-227.

9. Daenke, S.; Kermode, A.G.; Hall, S.E.; Taylor, G.; Weber, J.; Nightingale, S.; Bangham, C.R. High activated and memory cytotoxic T-cell responses to HTLV-1 in healthy carriers and patients with tropical spastic paraparesis. Virology 1996, 217, 139-146.

10. Jeffery, K.J.; Usuku, K.; Hall, S.E.; Matsumoto, W.; Taylor, G.P.; Procter, J.; Bunce, M.; Ogg, G.S.; Welsh, K.I.; Weber, J.N.; Lloyd, A.L.; Nowak, M.A.; Nagai, M.; Kodama, D.; Izumo, S.; Osame, M.; Bangham, C.R. HLA alleles determine human T-lymphotropic virus-I (HTLV-I) proviral load and the risk of HTLV-I-associated myelopathy. Proc. Natl. Acad. Sci. U S A 1999, 96, 3848-3853.

11. Asquith, B.; Zhang, Y.; Mosley, A.J.; de Lara, C.M.; Wallace, D.L.; Worth, A.; Kaftantzi, L.; Meekings, K.; Griffin, G.E.; Tanaka, Y.; Tough, D.F.; Beverley, P.C.; Taylor, G.P.; Macallan, D.C.; Bangham, C.R. In vivo T lymphocyte dynamics in humans and the impact of human Tlymphotropic virus 1 infection. Proc. Natl. Acad. Sci. U S A 2007, 104, 8035-8040. 
12. Sommerfelt, M.A.; Williams, B.P.; Clapham, P.R.; Solomon, E.; Goodfellow, P.N.; Weiss, R.A. Human $\mathrm{T}$ cell leukemia viruses use a receptor determined by human chromosome 17. Science 1988, 242, 1557-1559.

13. Richardson, J.H.; Edwards, A.J.; Cruickshank, J.K.; Rudge, P.; Dalgleish, A.G. In vivo cellular tropism of human T-cell leukemia virus type 1. J. Virol. 1990, 64, 5682-5687.

14. Goon, P.K.; Igakura, T.; Hanon, E.; Mosley, A.J.; Barfield, A.; Barnard, A.L.; Kaftantzi, L.; Tanaka, Y.; Taylor, G.P.; Weber, J.N.; Bangham, C.R. Human T cell lymphotropic virus type I (HTLV-I)-specific CD4+ T cells: immunodominance hierarchy and preferential infection with HTLV-I. J. Immunol. 2004, 172, 1735-1743.

15. Hanon, E.; Asquith, R.E.; Taylor, G.P.; Tanaka, Y.; Weber, J.N.; Bangham, C.R. High frequency of viral protein expression in human $\mathrm{T}$ cell lymphotropic virus type 1-infected peripheral blood mononuclear cells. AIDS Res. Hum. Retroviruses 2000, 16, 1711-1715.

16. Hanon, E.; Hall, S.; Taylor, G.P.; Saito, M.; Davis, R.; Tanaka, Y.; Usuku, K.; Osame, M.; Weber, J.N.; Bangham, C.R. Abundant tax protein expression in CD4+ T cells infected with human T-cell lymphotropic virus type I (HTLV-I) is prevented by cytotoxic T lymphocytes. Blood 2000, 95, 1386-1392.

17. Uchiyama, T. Human T cell leukemia virus type I (HTLV-I) and human diseases. Annu. Rev. Immunol. 1997, 15, 15-37.

18. Hanon, E.; Stinchcombe, J.C.; Saito, M.; Asquith, B.E.; Taylor, G.P.; Tanaka, Y.; Weber, J.N.; Griffiths, G.M.; Bangham, C.R. Fratricide among CD8(+) T lymphocytes naturally infected with human T cell lymphotropic virus type I. Immunity 2000, 13, 657-664.

19. Nagai, M.; Brennan, M.B.; Sakai, J.A.; Mora, C.A.; Jacobson, S. CD8(+) T cells are an in vivo reservoir for human T-cell lymphotropic virus type I. Blood 2001, 98, 1858-1861.

20. Yamamoto, N.; Okada, M.; Koyanagi, Y.; Kannagi, M.; Hinuma, Y. Transformation of human leukocytes by cocultivation with an adult $\mathrm{T}$ cell leukemia virus producer cell line. Science $\mathbf{1 9 8 2}$, 217, 737-739.

21. Popovic, M.; Sarin, P.S.; Robert-Gurroff, M.; Kalyanaraman, V.S.; Mann, D.; Minowada, J.; Gallo, R.C. Isolation and transmission of human retrovirus (human t-cell leukemia virus). Science 1983, 219, 856-859.

22. Okochi, K.; Sato, H. Transmission of ATLV (HTLV-I) through blood transfusion. Princess Takamatsu Symp. 1984, 15, 129-135.

23. Li, H.C.; Biggar, R.J.; Miley, W.J.; Maloney, E.M.; Cranston, B.; Hanchard, B.; Hisada, M. Provirus load in breast milk and risk of mother-to-child transmission of human $\mathrm{T}$ lymphotropic virus type I. J. Infect. Dis. 2004, 190, 1275-1278.

24. Fujino, T.; Nagata, Y. HTLV-I transmission from mother to child. J. Reprod. Immunol. 2000, 47, 197-206.

25. Ureta-Vidal, A.; Angelin-Duclos, C.; Tortevoye, P.; Murphy, E.; Lepere, J.F.; Buigues, R.P.; Jolly, N.; Joubert, M.; Carles, G.; Pouliquen, J.F.; de The, G.; Moreau, J.P.; Gessain, A. Motherto-child transmission of human T-cell-leukemia/lymphoma virus type I: implication of high antiviral antibody titer and high proviral load in carrier mothers. Int. J. Cancer 1999, 82, 832-836.

26. Moriuchi, M.; Moriuchi, H. Seminal fluid enhances replication of human T-cell leukemia virus type 1: implications for sexual transmission. J. Virol. 2004, 78, 12709-12711. 
27. Mahieux, R.; Gessain, A. HTLV-1 and associated adult T-cell leukemia/lymphoma. Rev. Clin. Exp. Hematol. 2003, 7, 336-361.

28. Manns, A.; Hisada, M.; La Grenade, L. Human T-lymphotropic virus type I infection. Lancet 1999, 353, 1951-1958.

29. Fan, N.; Gavalchin, J.; Paul, B.; Wells, K.H.; Lane, M.J.; Poiesz, B.J. Infection of peripheral blood mononuclear cells and cell lines by cell-free human T-cell lymphoma/leukemia virus type I. J. Clin. Microbiol. 1992, 30, 905-910.

30. Goon, P.K.; Hanon, E.; Igakura, T.; Tanaka, Y.; Weber, J.N.; Taylor, G.P.; Bangham, C.R. High frequencies of Th1-type CD4(+) T cells specific to HTLV-1 Env and Tax proteins in patients with HTLV-1-associated myelopathy/tropical spastic paraparesis. Blood 2002, 99, 3335-3341.

31. Grakoui, A.; Bromley, S.K.; Sumen, C.; Davis, M. M.; Shaw, A.S.; Allen, P.M.; Dustin, M.L. The immunological synapse: a molecular machine controlling T cell activation. Science 1999, 285, 221-227.

32. Igakura, T.; Stinchcombe, J.C.; Goon, P.K.; Taylor, G.P.; Weber, J.N.; Griffiths, G.M.; Tanaka, Y.; Osame, M.; Bangham, C. R. Spread of HTLV-I between lymphocytes by virus-induced polarization of the cytoskeleton. Science 2003, 299, 1713-1716.

33. Stinchcombe, J.C.; Griffiths, G.M. Secretory mechanisms in cell-mediated cytotoxicity. Annu. Rev. Cell Dev. Biol. 2007, 23, 495-517.

34. Jenkins, M.R.; Tsun, A.; Stinchcombe, J.C.; Griffiths, G.M. The strength of T cell receptor signal controls the polarization of cytotoxic machinery to the immunological synapse. Immunity 2009, 31, 621-631.

35. Nejmeddine, M.; Barnard, A.L.; Tanaka, Y.; Taylor, G.P.; Bangham, C.R. Human Tlymphotropic virus, type 1 , tax protein triggers microtubule reorientation in the virological synapse. J. Biol. Chem. 2005, 280, 29653-29660.

36. Nejmeddine, M.; Negi, V.S.; Mukherjee, S.; Tanaka, Y.; Orth, K.; Taylor, G.P.; Bangham, C.R. HTLV-1-Tax and ICAM-1 act on T-cell signal pathways to polarize the microtubule-organizing center at the virological synapse. Blood 2009, 114, 1016-1025.

37. Mazurov, D.; Ilinskaya, A.; Heidecker, G.; Lloyd, P.; Derse, D. Quantitative Comparison of HTLV-1 and HIV-1 Cell-to-Cell Infection with New Replication Dependent Vectors. PLoS Pathog. 2010, 6, e1000788.

38. Feng, X.; Heyden, N.V.; Ratner, L. Alpha interferon inhibits human T-cell leukemia virus type 1 assembly by preventing Gag interaction with rafts. J. Virol. 2003, 77, 13389-13395.

39. Heidecker, G.; Lloyd, P.A.; Fox, K.; Nagashima, K.; Derse, D. Late assembly motifs of human Tcell leukemia virus type 1 and their relative roles in particle release. J. Virol. 2004, 78, 6636-6648.

40. Blot, V.; Perugi, F.; Gay, B.; Prevost, M.C.; Briant, L.; Tangy, F.; Abriel, H.; Staub, O.; Dokhelar, M.C.; Pique, C. Nedd4.1-mediated ubiquitination and subsequent recruitment of Tsg101 ensure HTLV-1 Gag trafficking towards the multivesicular body pathway prior to virus budding. J. Cell Sci. 2004, 117, 2357-2367.

41. Majorovits, E.; Nejmeddine, M.; Tanaka, Y.; Taylor, G.P.; Fuller, S.D.; Bangham, C.R. Human T-lymphotropic virus-1 visualized at the virological synapse by electron tomography. PLoS One 2008, 3, e2251. 
42. Le Blanc, I.; Blot, V.; Bouchaert, I.; Salamero, J.; Goud, B.; Rosenberg, A.R.; Dokhelar, M.C. Intracellular distribution of human T-cell leukemia virus type $1 \mathrm{Gag}$ proteins is independent of interaction with intracellular membranes. J. Virol. 2002, 76, 905-911.

43. Alefantis, T.; Mostoller, K.; Jain, P.; Harhaj, E.; Grant, C.; Wigdahl, B. Secretion of the human T cell leukemia virus type I transactivator protein tax. J. Biol. Chem. 2005, 280, 17353-17362.

44. Lamsoul, I.; Lodewick, J.; Lebrun, S.; Brasseur, R.; Burny, A.; Gaynor, R.B.; Bex, F. Exclusive ubiquitination and sumoylation on overlapping lysine residues mediate NF-kappaB activation by the human T-cell leukemia virus tax oncoprotein. Mol. Cell Biol. 2005, 25, 10391-10406.

45. Harhaj, N.S.; Sun, S.C.; Harhaj, E.W. Activation of NF-kappa B by the human T cell leukemia virus type I Tax oncoprotein is associated with ubiquitin-dependent relocalization of I kappa B kinase. J. Biol. Chem. 2007, 282, 4185-4192.

46. Nasr, R.; Chiari, E.; El-Sabban, M.; Mahieux, R.; Kfoury, Y.; Abdulhay, M.; Yazbeck, V.; Hermine, O.; de The, H.; Pique, C.; Bazarbachi, A. Tax ubiquitylation and sumoylation control critical cytoplasmic and nuclear steps of NF-kappaB activation. Blood 2006, 107, 4021-4029.

47. Barnard, A.L.; Igakura, T.; Tanaka, Y.; Taylor, G.P.; Bangham, C.R. Engagement of specific Tcell surface molecules regulates cytoskeletal polarization in HTLV-1-infected lymphocytes. Blood 2005, 106, 988-995.

48. Burton, J.; Goldman, C.K.; Rao, P.; Moos, M.; Waldmann, T.A. Association of intercellular adhesion molecule 1 with the multichain high-affinity interleukin 2 receptor. Proc. Natl. Acad. Sci. U S A 1990, 87, 7329-7333.

49. Geiger, T.R.; Sharma, N.; Kim, Y.M.; Nyborg, J.K. The human T-cell leukemia virus type 1 tax protein confers $\mathrm{CBP} / \mathrm{p} 300$ recruitment and transcriptional activation properties to phosphorylated CREB. Mol. Cell Biol. 2008, 28, 1383-1392.

50. Nicot, C.; Tie, F.; Giam, C.Z. Cytoplasmic forms of human T-cell leukemia virus type 1 Tax induce NF-kappaB activation. J. Virol. 1998, 72, 6777-6784.

51. Kfoury, Y.; Nasr, R.; Favre-Bonvin, A.; El-Sabban, M.; Renault, N.; Giron, M.L.; Setterblad, N.; Hajj, H.E.; Chiari, E.; Mikati, A.G.; Hermine, O.; Saib, A.; de The, H.; Pique, C.; Bazarbachi, A. Ubiquitylated Tax targets and binds the IKK signalosome at the centrosome. Oncogene 2008, 27, 1665-1676.

52. Winter, H.Y.; Marriott, S.J. Human T-cell leukemia virus type 1 Tax enhances serum response factor DNA binding and alters site selection. J. Virol. 2007, 81, 6089-6098.

53. Grassmann, R.; Aboud, M.; Jeang, K.T. Molecular mechanisms of cellular transformation by HTLV-1 Tax. Oncogene 2005, 24, 5976-5985.

54. Lebedeva, T.; Dustin, M.L.; Sykulev, Y. ICAM-1 co-stimulates target cells to facilitate antigen presentation. Curr. Opin. Immunol. 2005, 17, 251-258.

55. Thompson, P.W.; Randi, A.M.; Ridley, A.J. Intercellular adhesion molecule (ICAM)-1, but not ICAM-2, activates RhoA and stimulates c-fos and rhoA transcription in endothelial cells. J. Immunol. 2002, 169, 1007-1013.

56. Gardiner, E.E.; D'Souza, S.E. Sequences within fibrinogen and intercellular adhesion molecule-1 (ICAM-1) modulate signals required for mitogenesis. J. Biol. Chem. 1999, 274, 11930-11936.

57. Copeland, K.F.; Haaksma, A.G.; Derse, D.; Heeney, J.L. Detection of human T-cell leukaemia virus 1 permissive cells using cell lines producing selectable recombinant virions. J. Virol. Methods 1994, 50, 219-225. 
58. Hildreth, J.E.; Subramanium, A.; Hampton, R.A. Human T-cell lymphotropic virus type 1 (HTLV-1)-induced syncytium formation mediated by vascular cell adhesion molecule-1: evidence for involvement of cell adhesion molecules in HTLV-1 biology. J. Virol. 1997, 71, 1173-1180.

59. Daenke, S.; McCracken, S.A.; Booth, S. Human T-cell leukaemia/lymphoma virus type 1 syncytium formation is regulated in a cell-specific manner by ICAM-1, ICAM-3 and VCAM-1 and can be inhibited by antibodies to integrin beta2 or beta7. J. Gen. Virol. 1999, 80, 1429-1436.

60. Yamamoto, A.; Hara, H.; Kobayashi, T. Induction of the expression of gag protein in HTLV-I infected lymphocytes by anti-ICAM 1 antibody in vitro. J. Neurol. Sci. 1997, 151, 121-126.

61. Fukudome, K.; Furuse, M.; Fukuhara, N.; Orita, S.; Imai, T.; Takagi, S.; Nagira, M.; Hinuma, Y.; Yoshie, O. Strong induction of ICAM-1 in human T cells transformed by human T-cell-leukemia virus type 1 and depression of ICAM-1 or LFA-1 in adult T-cell-leukemia-derived cell lines. Int. J. Cancer 1992, 52, 418-427.

62. Tanaka, Y.; Fukudome, K.; Hayashi, M.; Takagi, S.; Yoshie, O. Induction of ICAM-1 and LFA-3 by Tax 1 of human T-cell leukemia virus type 1 and mechanism of down-regulation of ICAM-1 or LFA-1 in adult-T-cell-leukemia cell lines. Int. J. Cancer 1995, 60, 554-561.

63. Tanaka, Y.; Hayashi, M.; Takagi, S.; Yoshie, O. Differential transactivation of the intercellular adhesion molecule 1 gene promoter by Tax 1 and Tax 2 of human T-cell leukemia viruses. J. Virol. 1996, 70, 8508-8517.

64. Owen, S.M.; Rudolph, D.L.; Dezzutti, C.S.; Shibata, N.; Naik, S.; Caughman, S.W.; Lal, R.B. Transcriptional activation of the intercellular adhesion molecule 1 (CD54) gene by human $\mathrm{T}$ lymphotropic virus types I and II Tax is mediated through a palindromic response element. AIDS Res. Hum. Retroviruses 1997, 13, 1429-1437.

65. Hubner, W.; McNerney, G.P.; Chen, P.; Dale, B.M.; Gordon, R.E.; Chuang, F.Y.; Li, X.D.; Asmuth, D.M.; Huser, T.; Chen, B.K. Quantitative 3D video microscopy of HIV transfer across T cell virological synapses. Science 2009, 323, 1743-1747.

66. Banerjee, P.; Feuer, G.; Barker, E. Human T-cell leukemia virus type 1 (HTLV-1) p12I downmodulates ICAM-1 and -2 and reduces adherence of natural killer cells, thereby protecting HTLV-1-infected primary CD4+ T cells from autologous natural killer cell-mediated cytotoxicity despite the reduction of major histocompatibility complex class I molecules on infected cells. J. Virol. 2007, 81, 9707-9717.

67. Kim, S.J.; Nair, A.M.; Fernandez, S.; Mathes, L.; Lairmore, M.D. Enhancement of LFA-1mediated $\mathrm{T}$ cell adhesion by human $\mathrm{T}$ lymphotropic virus type 1 p12I1. J. Immunol. 2006, 176, 5463-5470.

68. Yin, M.J.; Christerson, L.B.; Yamamoto, Y.; Kwak, Y.T.; Xu, S.; Mercurio, F.; Barbosa, M.; Cobb, M.H.; Gaynor, R.B. HTLV-I Tax protein binds to MEKK1 to stimulate IkappaB kinase activity and NF-kappaB activation. Cell 1998, 93, 875-884.

69. Wu, K.; Bottazzi, M.E.; de la Fuente, C.; Deng, L.; Gitlin, S.D.; Maddukuri, A.; Dadgar, S.; Li, H.; Vertes, A.; Pumfery, A.; Kashanchi, F. Protein profile of tax-associated complexes. J. Biol. Chem. 2004, 279, 495-508.

70. Biberfeld, P.; Mellstedt, H.; Pettersson, D. Ultrastructural and immunocytochemical characterization of circulating mononuclear cells in patients with myelomatosis. Acta. Pathol. Microbiol. Scand. A. 1977, 85, 611-624. 
71. Kirchhausen, T.; Staunton, D.E.; Springer, T.A. Location of the domains of ICAM-1 by immunolabeling and single-molecule electron microscopy. J. Leukoc. Biol. 1993, 53, 342-346.

72. Yang, Y.; Jun, C.D.; Liu, J.H.; Zhang, R.; Joachimiak, A.; Springer, T.A.; Wang, J.H. Structural basis for dimerization of ICAM-1 on the cell surface. Mol. Cell 2004, 14, 269-276.

73. Martin, N.; Welsch, S.; Jolly, C.; Briggs, J.A.; Vaux, D.; Sattentau, Q.J. Virological SynapseMediated Spread of Human Immunodeficiency Virus Type 1 between T Cells Is Sensitive to Entry Inhibition. J. Virol. 2010, 84, 3516-3527.

74. Stinchcombe, J.C.; Bossi, G.; Booth, S.; Griffiths, G.M. The immunological synapse of CTL contains a secretory domain and membrane bridges. Immunity 2001, 15, 751-761.

75. Stinchcombe, J.C.; Majorovits, E.; Bossi, G.; Fuller, S.; Griffiths, G.M. Centrosome polarization delivers secretory granules to the immunological synapse. Nature 2006, 443, 462-465.

76. Briggs, J.A.; Wilk, T.; Welker, R.; Krausslich, H.G.; Fuller, S.D. Structural organization of authentic, mature HIV-1 virions and cores. EMBO J. 2003, 22, 1707-1715.

77. Fuller, S.D.; Wilk, T.; Gowen, B.E.; Krausslich, H.G.; Vogt, V.M. Cryo-electron microscopy reveals ordered domains in the immature HIV-1 particle. Curr. Biol. 1997, 7, 729-738.

78. Jones, K.S.; Petrow-Sadowski, C.; Huang, Y.K.; Bertolette, D.C.; Ruscetti, F.W. Cell-free HTLV1 infects dendritic cells leading to transmission and transformation of CD4(+) T cells. Nat. Med. 2008, 14, 429-436.

79. Courreges, M.C.; Burzyn, D.; Nepomnaschy, I.; Piazzon, I.; Ross, S.R. Critical role of dendritic cells in mouse mammary tumor virus in vivo infection. J. Virol. 2007, 81, 3769-3777.

80. Pohl, C.; Shishkova, J.; Schneider-Schaulies, S. Viruses and dendritic cells: enemy mine. Cell Microbiol. 2007, 9, 279-289.

81. Wu, L.; KewalRamani, V.N. Dendritic-cell interactions with HIV: infection and viral dissemination. Nat. Rev. Immunol. 2006, 6, 859-868.

82. Ghez, D.; Lepelletier, Y.; Lambert, S.; Fourneau, J.M.; Blot, V.; Janvier, S.; Arnulf, B.; van Endert, P.M.; Heveker, N.; Pique, C.; Hermine, O. Neuropilin-1 is involved in human T-cell lymphotropic virus type 1 entry. J. Virol. 2006, 80, 6844-6854.

83. Jones, K.S.; Petrow-Sadowski, C.; Bertolette, D.C.; Huang, Y.; Ruscetti, F.W. Heparan sulfate proteoglycans mediate attachment and entry of human T-cell leukemia virus type 1 virions into CD4+ T cells. J. Virol. 2005, 79, 12692-12702.

84. Pinon, J.D.; Klasse, P.J.; Jassal, S.R.; Welson, S.; Weber, J.; Brighty, D.W.; Sattentau, Q.J. Human T-cell leukemia virus type 1 envelope glycoprotein gp46 interacts with cell surface heparan sulfate proteoglycans. J. Virol. 2003, 77, 9922-9930.

85. Lambert, S.; Bouttier, M.; Vassy, R.; Seigneuret, M.; Petrow-Sadowski, C.; Janvier, S.; Heveker, N.; Ruscetti, F.W.; Perret, G.; Jones, K.S.; Pique, C. HTLV-1 uses HSPG and neuropilin-1 for entry by molecular mimicry of VEGF165. Blood 2009, 113, 5176-5185.

86. Chung, J.S.; Dougherty, I.; Cruz, P.D., Jr.; Ariizumi, K. Syndecan-4 mediates the coinhibitory function of DC-HIL on T cell activation. J. Immunol. 2007, 179, 5778-5784.

87. Tordjman, R.; Lepelletier, Y.; Lemarchandel, V.; Cambot, M.; Gaulard, P.; Hermine, O.; Romeo, P.H. A neuronal receptor, neuropilin-1, is essential for the initiation of the primary immune response. Nat. Immunol. 2002, 3, 477-482. 
88. Ceccaldi, P.E.; Delebecque, F.; Prevost, M.C.; Moris, A.; Abastado, J.P.; Gessain, A.; Schwartz, O.; Ozden, S. DC-SIGN facilitates fusion of dendritic cells with human T-cell leukemia virus type 1-infected cells. J. Virol. 2006, 80, 4771-4780.

89. Jain, P.; Manuel, S.L.; Khan, Z.K.; Ahuja, J.; Quann, K.; Wigdahl, B. DC-SIGN mediates cellfree infection and transmission of human T-cell lymphotropic virus type 1 by dendritic cells. J. Virol. 2009, 83, 10908-10921.

90. Makino, M.; Shimokubo, S.; Wakamatsu, S.I.; Izumo, S.; Baba, M. The role of human Tlymphotropic virus type 1 (HTLV-1)-infected dendritic cells in the development of HTLV-1associated myelopathy/tropical spastic paraparesis. J. Virol. 1999, 73, 4575-4581.

91. Hishizawa, M.; Imada, K.; Kitawaki, T.; Ueda, M.; Kadowaki, N.; Uchiyama, T. Depletion and impaired interferon-alpha-producing capacity of blood plasmacytoid dendritic cells in human Tcell leukaemia virus type I-infected individuals. Br. J. Haematol. 2004, 125, 568-575.

92. Macatonia, S.E.; Cruickshank, J.K.; Rudge, P.; Knight, S.C. Dendritic cells from patients with tropical spastic paraparesis are infected with HTLV-1 and stimulate autologous lymphocyte proliferation. AIDS Res. Hum. Retroviruses 1992, 8, 1699-1706.

93. Pais-Correia, A.M.; Sachse, M.; Guadagnini, S.; Robbiati, V.; Lasserre, R.; Gessain, A.; Gout, O.; Alcover, A.; Thoulouze, M.I. Biofilm-like extracellular viral assemblies mediate HTLV-1 cell-tocell transmission at virological synapses. Nat. Med. 16, 83-89.

94. Jin, J.; Sherer, N.M.; Heidecker, G.; Derse, D.; Mothes, W. Assembly of the murine leukemia virus is directed towards sites of cell-cell contact. PLoS Biol. 2009, 7, e1000163.

95. Sherer, N.M.; Jin, J.; Mothes, W. Directional Spread of Surface-Associated Retroviruses Regulated by Differential Virus-Cell Interactions. J. Virol. 2010, 84, 3248-3258.

96. Rudnicka, D.; Feldmann, J.; Porrot, F.; Wietgrefe, S.; Guadagnini, S.; Prevost, M.C.; Estaquier, J.; Haase, A.T.; Sol-Foulon, N.; Schwartz, O. Simultaneous cell-to-cell transmission of human immunodeficiency virus to multiple targets through polysynapses. J. Virol. 2009, 83, 6234-6246.

97. Depoil, D.; Zaru, R.; Guiraud, M.; Chauveau, A.; Harriague, J.; Bismuth, G.; Utzny, C.; Muller, S.; Valitutti, S. Immunological synapses are versatile structures enabling selective $\mathrm{T}$ cell polarization. Immunity 2005, 22, 185-194.

98. Marsh, M.; Helenius, A. Virus entry: open sesame. Cell 2006, 124, 729-740.

99. Doms, R.W.; Trono, D. The plasma membrane as a combat zone in the HIV battlefield. Genes Dev. 2000, 14, 2677-2688.

100. Smith, A.E.; Helenius, A. How viruses enter animal cells. Science 2004, 304, 237-242.

101. Sieczkarski, S.B.; Whittaker, G.R. Differential requirements of Rab5 and Rab7 for endocytosis of influenza and other enveloped viruses. Traffic 2003, 4, 333-343.

102. Miyauchi, K.; Kim, Y.; Latinovic, O.; Morozov, V.; Melikyan, G.B. HIV enters cells via endocytosis and dynamin-dependent fusion with endosomes. Cell 2009, 137, 433-444.

(C) 2010 by the authors; licensee MDPI, Basel, Switzerland. This article is an Open Access article distributed under the terms and conditions of the Creative Commons Attribution license (http://creativecommons.org/licenses/by/3.0/). 